\title{
Menguak Nilai Dan Makna Di Balik Praktik Penentuan Harga Sewa: Studi Fenomenologis Pada Pengusaha Kos-Kosan Danang Prasdika 1, Robiatul Auliyah ${ }^{2}$, Achdiar Redy Setiawan ${ }^{3}$
}

\author{
Fakultas Ekonomi dan Bisnis \\ Universitas Trunojoyo Madura \\ Jl. Raya telang PO.BOX 2 Kamal, Bangkalan-Madura
}

\section{A R T I C L E I N F O}

Article history:

Received 26 April 2018

Revised 12 Mei 2018

Accepted 14 Juni 2018

\section{Keywords:}

Value Relevance, Book value and profit, Fair Value, Ohlson Model (1995), Mechanism of Good Corporate Governance.

\begin{abstract}
A B S T R A C T
This research seeks to expose the practice of determining rental rates on business services room kos-kosan named Kos Putra Mulya. The purpose of this researchis to know the practices of the determination of rents that occur as well as uncovering the value and the meaning behind these practices. This study uses qualitative methodsas tools in the process of the discoveryanswers and use the knife as a phenomenology analysis approach to answer the value and its meanings. The results showed in the method of determining the price of rent conducted by Kos Putra Mulyawas not based on the total cost of the activity of search efforts, but onlyusing the process of "estimate" in determining the costper-room.This is due to the presence of mutual cultural influence in its Treasury activities. In addition, there is cultural gotong royong, owners also instill a sense of brotherhood in every effort suffered, so that business owners regard the tenants is part of the family. And the last, the process of extracting the consciousness to find meaning in the term profit increase, i.e. the profit is defined as "rezekinya", while if the lossesmeant "bukan rezekinya".
\end{abstract}

\begin{abstract}
A B S T R A K
Penelitian ini berupaya mengungkap praktik penentuan harga sewa pada usaha jasa sewa kamar kos-kosan yang bernama Kos Putra Mulya. Tujuan Penelitian ini yaitu untuk mengetahui praktik penentuan harga sewa yang terjadi serta mengungkap nilai dan pemaknaan dibalik praktik tersebut. Penelitian ini menggunakan metode kualitatif sebagai alat dalam proses penemuan jawaban dan menggunakan pendekatan fenomenologi sebagai pisau analisis untuk menjawab nilai dan pemaknaannya. Hasil penelitian menunjukkan dalam metode penentuan harga sewa yang dilakukan oleh Kos Putra Mulya tidak berdasarkan penelusuran total biaya aktivitas usaha, namun hanya menggunakan proses "perkiraan" dalam menentukan biaya perkamar.

Hal ini dikarenakan adanya pengaruh budaya gotong royong dalam aktivitas keuangannya. Selain terdapatnya nilai budaya gotong-royong, pemilik juga menanamkan rasa persaudaraan dalam setiap usaha yang dijalaninya, sehingga pemilik usaha menganggap penyewa merupakan bagian dari keluarga. Dan yang terakhir, proses penggalian kesadaran menemukan makna laba dalam istilah keberkahan, yaitu laba diartikan sebagai "sudah rezekinya", sedangkan jika mengalami kerugian dimaknai "bukan rezekinya".
\end{abstract}

\section{PENDAHULUAN}

Membuka usaha kos-kosan ternyata mempunyai prospek yang cukup tinggi. Seperti yang dijelaskan oleh Mabrur (2016), untuk membuka usaha kos-kosan tidak perlu membuat lahan tempat usaha, cukup bagi yang sudah mempunyai aset properti tanah atau rumah pribadi maka sudah merupakan modal usaha kos-kosan.
Tantangan membuka usaha kos-kosan. Karena usaha kos-kosan berbeda dengan jenis usaha lainnya. Ketika pada saat pembelian aset rumah atau tanah untuk membuat kos-kosan, pada saat itulah usaha sudah mencapai break even point. Koskosan adalah aset dan nilai dari properti sama dengan nilai uang. Sehingga ketika membeli bangunan atau tanah kemudian disewakan pada

\footnotetext{
1 prasdika52@gmail.com,2robiatul.auliyah@trunojoyo.ac.id,3achdiar.redy17@gmail.com
} 
saat itulah investasi yang sedang dilakukan sudah mencapai break even point.

Dari berbagai tantangan yang telah dipaparkan oleh Mabrur (2016) tadi, tidak menghalangi niat para pengusaha untuk mendirikan usahanya, karena mengingat prospek dari bisnis jasa sewa kamar kos ini sangat menggiurkan. Seperti halnya yang diungkapkan oleh Budiarto (2015) dalam Oktavianingtyas (2015:1), bisnis kos-kosan adalah salah satu bisnis yang paling stabil di Indonesia, dan bisnis tersebut menjadi salah satu incaran pajak daerah yang kini kian tumbuh pesat dan menjadi ladang bisnis yang sangat menggiurkan bagi para pemilik modal untuk berinvestasi.

Untuk menjalankan bisnis usaha tersebut, tentunya diperlukan suatu metode atau perhitungan atas suatu jasa untuk menentukan berapa harga sewa yang dipatok oleh pemilik usaha atas kamar kos yang disewa. Selain untuk menentukan harga sewa per-kamar, pemilik tentunya juga akan menentukan periode pembayaran sewa untuk jasa kamar yang akan diberikan kepada penyewa selama periode tertentu. Dalam artian, pemilik akan menetapkan apakah pembayaran sewa kamar kos dilakukan dalam bulanan, atau dibayar langsung untuk satu tahun masa sewa.

Penentuan harga dijelaskan oleh Hansen dan Mowen (2009:102) yang mengatakan bahwa harga jual sebagai jumlah ukuran moneter yang dibebankan oleh suatu unit usaha kepada konsumen atau pelanggan atas barang atau jasa yang dijual. Hal senada juga dikatakan oleh Mulyadi (2014:78) yang menambahkan bahwa pada prinsipnya harga jual harus dapat menutupi biaya yang kemudian ditambah dengan laba yang wajar. Dengan begitu, untuk menentukan harga jual suatu produk atau jasa akan memperhitungkan jumlah biaya yang terjadi dengan keuntungan yang diharapkan oleh produsen.

Lebih lanjut, kajian ilmiah tentang penentuan harga sewa pernah diteliti oleh Riediansyaf dan Basuki (2013). Penelitiannya yang berjudul Designing Time-Driven Activity-Based Costing (TDABC) in the Room Division at Hotel X Malang, mendedahkan bahwa terkait tentang struktur biaya haruslah akurat, karena akan membantu manajemen dalam pengambilan keputusan. Penelitian ini dilakukan Hotel X Malang, dengan penerapan TDABC, yaitu menekankan penggunaan waktu sebagai dasar untuk menghitung biaya. Hasil penelitiannya, jika dibandingkan dengan perhitungan yang dilakukan perusahaan yaitu metode klasifikasi biaya, tingkat keakuratan metode TDABC lebih tinggi dan flexibel dalam perhitungan biaya dasar pada biaya kapasitas perusahaan. Selain itu, terdapat dua temuan yang dianalisis berdasarkan metode TDABC, yaitu pada tahun 2011, layanan sewa kamar pada Hotel X hanya menyerap rata-rata $30 \%$ dari sumber daya yang disediakan, dan yang kedua selama ini ternyata Hotel $\mathrm{X}$ beroperasi dengan margin keuntungan yang terlalu tinggi terutama untuk kamar kelas Junior Suite, dan Royal Suite.

Menentukan harga jual sangat erat kaitannya dengan prediksi keuntungan yang akan diperoleh dengan memperhitungkan biaya-biaya yang dibebankan dalam suatu kegiatan usaha. Akan tetapi, kerugian akan timbul jika harga jual yang ditetapkan di bawah biaya-biaya yang terjadi. Oleh karena itu, dalam penetapan harga jual, tingkat harga minimal hendaknya dapat menutupi semua biaya yang telah dipergunakan untuk memproduksi dan memasarkan barang atau jasa.

Fenomena yang peneliti temui, jika ditelusuri pada suatu teori yang telah diungkap oleh Hansen dan Mowen (2001:633) serta Mulyadi (2001:78), harga jual yang seharusnya dipatok oleh produsen minimal dapat menutupi biaya yang terjadi, tidak terefleksikan dengan jelas sebagai dasar penentuan harga jual yang terjadi di lapangan. Lantas, hal ini yang kemudian membuat rasa penasaran peneliti untuk menguak kebenarannya, dalam suatu perbuatan yang dilakukan pasti ada alasan dibalik itu semua.

Praktik bisnis saat ini masuk ke dalam era di mana usaha modern cenderung menginginkan laba besar tanpa memperhatikan aspek kemanusiaannya, serta unsur ketuhanan yang mulai hilang akibat tergerusnya oleh arus globalisasi. Praktik usaha yang secara orisinil ini lahir dan berkembang di masyarakat masih menyimpan kearifan lokal yang digali dalam nilainilai budaya lokal. Sehingga, keunikan ini menarik untuk dikuak mengingat usaha semacam ini berbeda dengan praktik usaha yang selama ini kita kenal.

Dalam konteks penelitian di Indonesia, mengenai penentuan harga jual pernah dilakukan oleh Alimuddin et al (2011), yaitu dalam penelitiannya bertujuan untuk menyusun konsep harga jual berbasis nilai kejujuran dalam islam. Penelitian ini dilakukan pada pemilik dan manajemen YDT dan Kopontren DT di Bandung, Charni's Productions di Yogyakarta, serta kedai Assalamu'alaikum dan rumah makan Bismillah di 
Malang. Penelitian dilakukan dengan menggunakan analisis epistemologi bayani, burhani dan irfani. Hasil penelitiannya menunjukkan, bahwa konsep harga jual berbasis nilai kejujuran dapat diklasifikasikan menjadi consistency cost-plus pricing, mekanisme pasar bersyarat serta mekanisme pasar keseimbangan dari epistemologi bayani, burhani dan irfani. Secara umum konsep harga jual berbasis nilai kejujuran di dalam Islam adalah consistency market mechanism, yaitu suatu konsep penetapan \}arga jual secara konsisten melalui mekanisme pasar sejak dari awal penetapan harganya hingga produk tersebut habis dijual.

Zalshabila dan Dedi (2012) juga melakukan penelitian senada. Penelitian yang berjudul Javanese Price Setting: Refleksi Fenomenologis Harga Pokok Produksi Pedagang Bakso Di Kota Malang ini, bertujuan untuk menganalisis aspek-aspek yang mendasari penentuan harga pokok produksi bakso, yang terefleksi pada penetapan harga jual suatu produk. Penelitian ini menggunakan pendekatan fenomenologi yang akan mengupas kesadaran mengenai proses penetapan harga pokok produksi, dengan harga jual bakso di mata pedagang itu sendiri. Hasil dalam penelitian ini, menemukan adanya Javanese price setting, di mana penentuan harga jual bakso bukanlah refleksi dari harga pokok produksi, melainkan refleksi dari budaya jawa yang dipegang oleh pedagang bakso. Budaya yang ada di pedagang bakso diantaranya tepo seliro, mangan ora mangan sing penting ngumpul, dan nerimo ing pandum.

Berdasarkan rujukan pada penelitian terdahulu tersebut, peneliti akan berfokus pada penentuan harga sewa yang menjadi keunikan tersendiri, serta nilai-nilai di balik penentuan harga sewa yang terjadi. Penelitian ini berangkat dari praktik bisnis yang berkembang di bidang sewa kamar kos-kosan yang bernama Kos Putra Mulya, yang memiliki keunikan dalam menjalankan bisnisnya. Kesadaran dari pengelola usaha yang mengedepankan nilai-nilai kemanusiaan serta tidak meniru pesaing dalam berlomba-lomba meraih keuntungan yang tinggi menjadi topik pembahasan peneliti.

Guna menjawab dari rasa penasaran peneliti, terdapat beberapa pertanyaan yang menjadi patokan dalam penelitian. Pertanyaan pertama adalah, bagaimana praktik penentuan harga sewa yang terjadi di Kos Putra Mulya?

Pertanyaan awal peneliti menjadi latar belakang dalam pertanyaan kedua, yaitu nilai-nilai apa saja yang terkandung dalam praktik penetuan harga sewa tersebut? Pertanyaan ini penting untuk diketahui, untuk menjawab dari suatu fenomena unik yang di temui peneliti. Sebagai pembatasan masalah, penelitian ini hanya berfokus pada praktik penentuan harga sewa serta nilai-nilai yang terkandung didalam praktik tersebut.

\section{METODE PENELITIAN}

Penelitian ini menggunakan metodologi kualitatif, yaitu mengkonstruksikan realita dan makna secara kultural dengan fokus pada proses dan peristiwa secara interaktif dimana otentisitas adalah kunci dalam metode ini, dan adanya keterlibatan peneliti dalam penelitian (Somantri, 2005:58). Dalam metode kualitatif, peneliti sebagai alat utama pengumpulan data yang berupa hasil wawancara dan pengamatan, kemudian pengambilan sampel data dilakukan secara purposif, dalam pengambilan dan pengumpulan sumber data menggunakan triangulasi, dan hasil penelitian berupa pemaknaan dari permasalahan yang diteliti (Rahmat, 2009:4).

Alasan penelitian ini menggunakan pendekatan kualitatif adalah karena dalam proses pengambilan data lebih mengutamakan perspektif emik, artinya lebih mementingkan paradigma narasumber, yaitu bagaimana ia memandang dunia dari segi pendiriannya (Rahmat, 2009:4). Oleh karena itu sebelum peneliti memulai penelitiannya, harus bisa memposisikan dirinya dalam sebuah paradigma (Kamayanti, 2016:12). Dalam proses pencarian jawaban dalam penelitian ini akan merujuk pada penggunaan data kualitatif yaitu berupa hasil wawancara, observasi, dan dokumentasi yang dianalisis melalui peneliti sebagai alat penelitian (Kamayanti, 2016:44), dan cenderung lebih mementingkan proses daripada hasil, yang artinya tujuan dari hasil penelitian kualitatif adalah untuk memperoleh pemahaman makna dari suatu fenomena (Rahmat, 2009:4). Dengan mengacu pada perspektif emik, dalam hal ini praktik penentuan harga sewa, maka peneliti berusaha menyelami kesadaran dari paradigma aktor, dan mengalir apa adanya sehingga temuan yang dapat disimpulkan melalui alat analisis lebih bersifat natural. Oleh karena itu, penggunaan metode kualitaif diharapkan dapat mengarahkan peneliti menemukan makna dibalik praktik penentuan harga sewa yang dilakukan oleh aktor.

Penelitian ini menggunakan pendekatan fenomenologi, yaitu mencoba menjelaskan atau mengungkap konsep pemaknaan dan pengalaman fenomena yang didasari oleh kesadaran yang terjadi pada individu (Rahmat, 2009:6). Pendekatan 
Fenomenologi pada awalnya diperkenalkan oleh J.H Lambert tahun 1764 untuk menunjukkan teori kebenaran. Kemudian pendekatan tersebut dicetuskan secara intens sebagai kajian filsafat pertama kali oleh Edmund Husserl (1859-1938), sehingga Husserl dipandang sebagai bapak Fenomenologi (Hasbiansyah, 2005:164). Adapun istilah fenomenologi secara etimologis berasal dari kata fenomenadan logos. Fenomenaberasal dari kata kerja berasal dari kata kerja yunani "phainesthai" yang berarti menampak, dan terbentuk dari akar kata fantasi, fantom, dan fosfor yang artinya sinar atau cahaya (Hajaroh, 2010:8).

Alasan penelitian ini menggunakan pendekatan fenomenologi, karena peneliti berusaha mendapatkan subjektivitas murni dari kesadaran para aktor untuk memaknai praktik penentuan harga sewa yang terjadi, yang nantinya akan mengidentifikasi setiap pemaknaan yang muncul dari para aktor. Seperti yang dijelaskan oleh Kamayanti (2016:150), pendekatan Fenomenologi dapat dijadikan sebuah alat analisis untuk mendapatkan subjektivitas murni, karena kebenaran ilmu yang diperoleh dari proses fenomenologi adalah kebenaran empiris yang subjektif. Hajaroh (2010:9)menambahkan, dalam model fenomenologi mempunyai konsep utama, yaitu makna. Untuk mengidentifikasi dari kesadaran diperlukan pemaknaan mendalam dari yang diteliti. Hajaroh (2010:9) melanjutkan, pemaknaan disini ibarat manusia yang sibuk dengan aktifitas nya, dan aktifitas tersebut penuh dengan pengalaman.

Seperti yang dijelaskan oleh Sugiyono (2010:390), dalam metode kualitatif tidak mengenal istilah populasi, melainkan informan. Begitupun juga dengan penelitian ini, yang menamai populasi adalah informan, informan utamanya yaitu pemilik dan pengelola Kos Putra Mulya. Hal senada juga dipaparkan oleh Moleong (2013:132) yang menegaskan bahwa seorang informan harus mempunyai banyak pengalaman tentang latar penelitian, karena akan membantu peneliti dalam mengungkap kesadaran dari informan. Kuswarno (2013:60) menjelaskan ada beberapa kriteria yang dapat dijadikan acuan dalam memilih informan pada penelitian fenomenologi, yaitu: pertama, informan harus mengalami langsung situasi atau kejadian yang berkaitan dengan topik penelitian, dengan tujuan untuk mendapatkan deskripsi dari sudut pandang orang pertama.

Kedua, informan mampu menggambarkan kembali fenomena yang telah dialaminya, terutama dalam sifat alamiah dan maknanya. Ketiga, bersedia untuk terlibat dalam kegiatan penelitian yang mungkin membutuhkan waktu yang lama. Keempat, bersedia untuk diwawancara dan direkam aktifitasnya selama wawancara atau selama penelitian berlangsung. Kelima, memberikan persetujuan untuk mempublikasikan hasil penelitian.

Tujuan utama dari pendekatan fenomenologi dalam penelitian ini adalah untuk mengungkap nilai, makna dan kesadaran dari pelaku bisnis yang bernama Kos Putra Mulya. Dalam praktik penentuan harga sewa kamarnya tidak berdasarkan jumlah biaya aktivitas yang terjadi, kajian teori yang menunjukkan bahwa tingkat keuntungan sebaiknya dapat menutupi jumlah biaya yang terjadi ini tidak tergambarkan dengan jelas pada seorang pengusaha kos-kosan ini, dan dalam melakukan usahanya tidak semata-mata ingin mencari keuntungan. Ketidaksesuaian dari praktik akuntansi yang selama ini dikenal dengan usaha yang berkembang di masyarakat ini perlu digali kebenarannya. Untuk mengungkap fenomena berdasarkan makna dan kesadaran dari para aktor, peneliti tertarik melakukan penelitian dengan pendekatan fenomenologi pada praktik penentuan biaya sewa di Kos Putra Mulya

\section{Situs Penelitian}

Dari eksplikasi teori mengenai penentuan harga, peneliti menemukan adanya ketidaksesuaian antara teori yang berlaku tentang konsep penentuan harga, dengan fenomena yang terjadi pada salah seorang pengusaha kos-kosan. Harga yang ditetapkan pada salah seorang pengusaha kos-kosan ini memiliki harga dibawah yang ditetapkan oleh pengusaha kos lainnya. Selain itu, seiring berjalannya waktu menunjukkan inflasi terhadap kebutuhan pokok, namun harga sewa yang dipatok tetaplah sama, tidak menaikkan harga sewa seperti pada kebanyakan pengusaha kos lainnya.

Peneliti memilih Kos Putra Mulya sebagai situs yang terletak di desa Telang kabupaten Bangkalan guna memperoleh informasi dengan praktik penentuan harga sewa yang terjadi. Hal ini karena desa telang sedang mengalami perkembangan infrastruktur dengan berdirinya sebuah Perguruan Tinggi Negeri yang berkembang di desa tersebut, dan pastinya disetiap sudut desa orang mulai berlomba-lomba untuk memulai bisnis kos-kosan.

Berdasarkan observasi awal, usaha yang dijalankan oleh pengusaha tersebut tidak sematamata mencari keuntungan dalam usaha yang 
dijalaninya, tidak selalu mementingkan laba untuk memperkaya diri dan tidak meniru pesaing lainnya dalam hal menentukan tarif sewa kamar. Dalam aktivitas keuangan khususnya pada penentuan harga sewa, pengusaha kos tersebut tidak memasukan biaya perawatan ke dalam suatu perhitungan harga sewa, sehingga tarif yang dipatok cukup murah yakni sebesar Rp270.000 untuk satu kamarnya. Dalam pengakuannya, pemilik usaha kos tersebut memiliki metode sendiri dalam menentukan tarif sewa kamar, dan tidak mengikuti pengusaha kos di sekelilingnya untuk menaikkan harga dan mengubah sistem masa pembayaran.

Mematok harga yang berbeda dari pengusaha kos lainnya, bukan berarti usaha yang dijalani oleh pengusaha kos tersebut selalu berjalan dengan baik. Seperti konsumen yang menunggak bayar, bahkan penyewa yang kabur pun pernah dijumpai. Namun menurut pengakuannya, pengelola sudah mengganggap penyewa tersebut layaknya keluarga sendiri, dan tidak ada gap atau jarak antara pemilik dengan konsumen, sehingga pengelola menganggap rugi dan untung adalah haknya.

Situs penelitian adalah tempat penelitian dilakukan. Situs penelitian ini merupakan salah satu usaha di bidang penyewaan kamar kos yang bernama Kos Putra Mulya. Usaha tersebut mempunyai 10 kamar, dan lokasi dari situs penelitian ini terletak di Desa Telang, Kecamatan Kamal, Kabupaten Bangkalan. Pertimbangan peneliti memilih Kos Putra Mulya sebagai situs penelitian yaitu, karena peneliti yang pernah menjadi konsumen Kos Putra Mulya selama 6 bulan, sehingga peneliti dapat mengalami kejadian langsung aktivitas keuangan yang terjadi. Terlebih ketika jumlah mahasiswa yang mengambil studi di kampus UTM semakin padat, usaha penyewaan kamar kos tentunya memiliki harga yang tinggi. Seperti pada hukum penawaran, semakin banyak permintaan terhadap suatu barang maka akan tinggi pula harganya. Namun berdasarakan observasi awal, para aktor mengaku tidak menaikkan harga sewanya semenjak awal usaha tersebut didirkan dan tidak mengubah sistem pembayaran sewa kos yang biasanya dilakukan selama bulanan menjadi dibebankan langsung 6 bulan sekali ataupun pertahun, inilah yang menjadi faktor utama peneliti tertarik memilih situs penelitian ini.

Dari pengalaman peneliti sebagai konsumen, dapat dijadikan akses lokasi yang bisa dijangkau. Akses menuju yang diteliti juga merupakan hal yang penting, karena akses adalah salah satu jalan utama peneliti dalam mengungkapkan suatu kejadian dan fenomena. Selain dapat memberi akses, peneliti yang pernah menjadi konsumen Kos Putra Mulya mempunyai kedekatan secara historis, seperti yang dijelaskan oleh Kamayanti (2016:151) pengalaman akan membentuk persepsi, ingatan, ekspektasi, serta fantasi yang berbeda. Karena itulah peneliti menjadi tertarik memilih Kos Putra Mulya sebagai situs penelitian. Keseluruhan faktor tersebut diharapkan dapat memberikan kemudahan bagi peneliti untuk menggali informasi yang lebih dalam mengenai praktik penentuan biaya sewa yang terjadi.

\section{Informan}

Seperti yang dijelaskan di awal, moleong menjelaskan informan adalah orang dalam penelitian yang dimanfaatkan untuk memberikan informasi. Dengan adanya informan, memudahkan peneliti dalam menjaring informasi yang dibutuhkan dalam penelitian ini. Berikut adalah mereka yang menjadi informan dalam penelitian ini, bukan nama sebenarnya.

Tabel 2.1

Daftar Informan

\begin{tabular}{|r|l|l|}
\hline \multicolumn{1}{|l|}{ No. } & \multicolumn{1}{|c|}{ Nama } & \multicolumn{1}{c|}{ Keterangan } \\
\hline 1 & Bapak Toni & Pemilik / Aktor utama \\
\hline 2 & Ibu Susi & Pemilik / Aktor utama \\
\hline 3 & Roni & $\begin{array}{l}\text { Konsumen / Aktor } \\
\text { pendukung }\end{array}$ \\
\hline 4 & Ibu Lisa & $\begin{array}{l}\text { Pengusaha kos lainnya } \\
\text { / Aktor pendukung }\end{array}$ \\
\hline
\end{tabular}

Sumber: data olahan 2017

Pertama, bapak Toni. Bapak Toni adalah pemilik sekaligus pengelola dari Kos Putra Mulya. Bapak yang satu ini sangat peduli dengan lingkungan nya. Bapak Toni juga merupakan aktor utama dalam konteks penelitian ini, karena beliau adalah yang menciptakan konsep penentuan harga sewa berdasarkan metode dan perhitungan nya sendiri. Kegiatan yang dilakukan oleh bapak Toni adalah mengelola usaha yang dijalani nya, merawat fasilitas yang berada di Kos Putra Mulya, melakukan pembayaran dari seluruh biaya operasi seperti biaya listrik, biaya perawatan fasilitas umum dan fasilitas kamar dan menagih pembayaran sewa kamar.

Kedua adalah ibu Susi. Beliau merupakan pengelola kedua juga sekaligus istri dari bapak Toni. Ibu Susi adalah orang yang peduli terhadap keamanan tempat usaha nya. Sistem yang dirancang sedemikian rupa seperti tamu harus 
lapor ke pengelola adalah salah satunya. Ini merupakan salah satu bentuk pengendalian internal yang dimiliki oleh usaha tersebut. Tugas dari ibu Susi adalah membantu dari bapak Toni, seperti membantu pencatatan keuangan, dan membantu menagih pembayaran sewa kamar.

Ketiga adalah Roni, adalah penyewa Kos Putra Mulya. Beliau adalah mahasiswa Universitas Trunojoyo Madura semester 9, yang sudah menjadi konsumen Kos Putra Mulya selama 3 tahun. Sehingga pengalaman dari praktik penentuan harga sewa yang dirasakan oleh konsumen dirasa lebih tepat jika peneliti mengambil informasi dari beliau. Yang terakhir adalah Ibu Lisa merupakan informan pendukung yang juga sebagai pengusaha kos-kosan lainnya. Informasi dari beliau sebagai pengunci kebenaran pada praktik penentuan harga sewa yang terjadi di Kos Putra Mulya.

Sejumlah informan tersebut bersedia meluangkan waktunya untuk membagikan pengalaman terkait dengan tujuan penelitian ini. Tentunya peneliti terlebih dahulu meminta kesediaan nya dalam memberikan informasi juga pengalaman mereka pada posisi yang ditempati pada saat penelitian.

\section{Teknik Analisis Data}

Setelah data-data yang diperlukan peneliti telah terkumpul, maka langkah awal membuat rerangka penelitian fenomenologi seperti yang dijelaskan oleh (Kuswarno, 2013) adalah melakukan intentional analysis dengan menggabungkan pemahaman subjektif (noesis)yang merupakan pemahaman subjektif para informan terkait pengalaman dalam penentuan harga sewa pada situs Kos Putra Mulya dan noema yang merupakan objek yang dipresepsikan informan yang meliputi tahap dan prosedur dalam menentukan biaya sewa kamar.

Langkah kedua, peneliti melakukan epoche, berkaitan dengan perilaku peneliti dalam melakukan penggalian data di lapangan secara personal menggunakan pertanyaan yang berkaitan dengan masalah yang terikat didalam para informan. Epoche merupakan gabungan dari noema dan noesis untuk mengungkap makna dari yang diteliti. Langkah ketiga melakukan eidetic reduction yang merupakan tahap penguraian dan pengungkapan realita yang telah diperoleh pada tahap epoche untuk menemukan pemaknaan dari fenomena di lapangan. Kesimpulan dari analisis data dalam penelitian ini adalah mengenai nilainilai apa saja yang terkandung dalam praktik penentuan harga sewa.

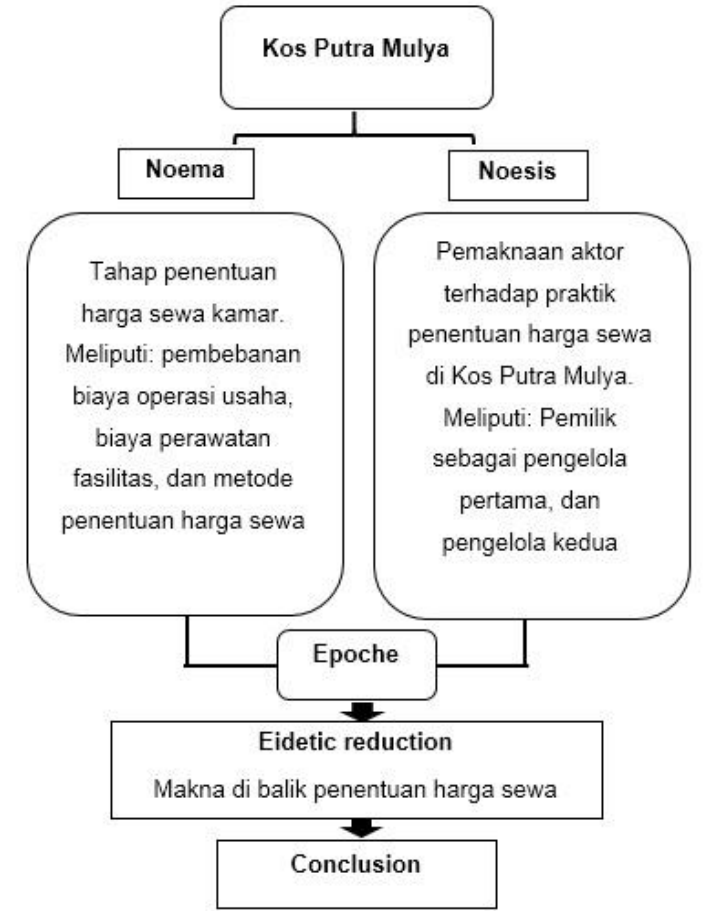

Gambar 2.1 Rerangka Penelitian

3. HASIL PENELITIAN

3.1 Enggak Ngikut Siapa-Siapa Dalam Menentukan Tarif Sewa

Usaha yang dijalani Bapak Toni dan Ibu Susi meskipun bukan termasuk dalam kategori pengusaha besar, tetapi dalam mengklasifikasikan biaya usaha untuk memprediksikan keuntungan yang diharapkan sangat diperlukan, ini terkait masalah pengambilan keputusan manajemen pemilik. Keputusan yang dimaksud di sini adalah mengenai rentang harga yang akan ditetapkan untuk harga jual yang akan diumumkan oleh penyewa. Seperti pada pengungkapan Bapak Toni, yang mendedahkan jika perhitungan harga sewanya tidak mengikuti harga pada pesaing lain, namun menggunakan perhitungan sendiri, berikut pernyataannya:

"saya \{enggak ngikut siapa-siapa\} tarif sewa kamarnya, untuk penentuan harganya saya bikin sendiri,", (Bapak Toni - pemilik)

Begitulah yang diungkapkan oleh Bapak Toni selaku pemilik usaha. Wawancara yang berlangsung di ruang tamu rumah pemilik ini berlangsung secara bersamaan dengan istri dari Bapak Toni sendiri. Seusai Bapak Toni mengungkapkan bahwa tarif yang saat ini tidak mengikuti pengusaha kos lainnya, saya pun bertanya bagaimana cara menentukan tarif sewa kamar yang dipatok oleh pemilik, cerita dari 
paparan sang aktor pun berlanjut seperti berikut:

"ya memang pake $\{$ itung-itung\}sendiri itu nak, ya harganya 270 itu belum naik hehe per kamar. ya 270 itu \{dikira-kira aja\} nak, dari lampu, terus ada biaya listriknya sudah itu, saya patok tarif lampunya tiap bulan itu kan 15.000 nak, terus perkamar nya itu saya tarik 270 tiap bulan, jadi totalnya 285 per kamar, tapi kalo yang gak bawa magicom, setrika itu memang gak saya tarik nak uang listriknya", (Ibu Susi - pemilik),

Dari paparan yang dikatakan oleh Ibu Susi tadi, Kos Putra Mulya memiliki dua kategori tipe pembayaran kamar, yang pertama bagi yang membawa peralatan yang mengkonsumsi daya listrik secara berlebih seperti magicom, setrika, televisi akan dikenakan tarif tambahan sebesar Rp15.000, namun bagi penyewa yang tidak membawa peralatan seperti di atas tidak dikenakan tarif tambahan. Dari dua kategori pembayaran untuk harga sewa kamar tersebut digambarkan sebagai berikut:

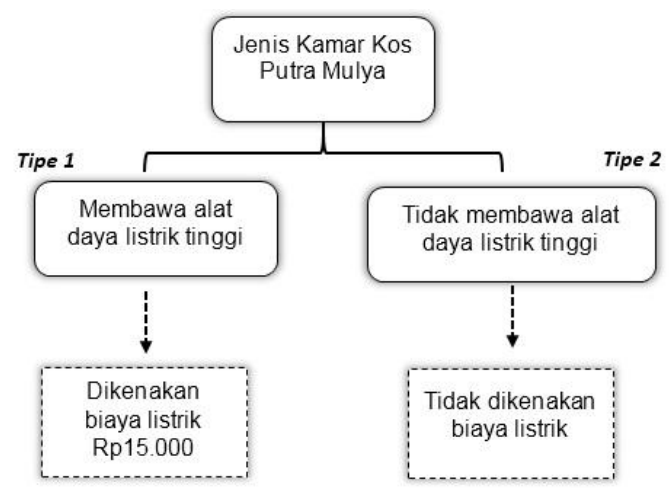

Gambar 3.2 TipeKamar Kos Putra Mulya Sumber: data olahan, informanIbu Susi

Berbicara mengenai jenis tipe kamar yang ada pada usaha Kos Putra Mulya, seperti yang dijelaskan oleh para aktor bahwa harga yang ditetapkan adalah sebesar Rp270.000, dan bagi yang ingin membawa peralatan lebih akan dikenakan biaya tambahan sebesar Rp15.000, maka dibutuhkan klasifikasi biaya yang dilakukan pemilik untuk memudahkan dalam pengambilan keputusan, keputusan yang dimaksud yaitu berapa harga yang dipatok oleh para aktor. Sesi wawancara kembali berlangsung, yang kemudian Bapak Toni menjelaskan tentang biaya apa saja yang timbul dalam menjalankan usahanya, berikut penuturan Bapak Japri:

"biaya-biaya ya kalo disini ini, untuk \{perawatannya\} biaya ganti kran air, kan anak-anak kalo make suka ngasal jadi cepet rusak itu kran air kamar mandi, terus kadang perbaikan sanyo, perbaikan kunci kamar, ya kadang diganti itu, suka rusak kan kalo kunci, jumlahnya ya \{gak tentu\}, kadang ini aja sekarang 4 pintu kuncinya rusak semua habis 120 , ya memang \{gak saya catet $\}$ kalo masalah biaya-biaya itu, kalo ada yang perlu diperbaiki \{yowis diperbaiki\} gitu aja", (Bapak Toni - pemilik)

Dari paparan sang aktor utama dalam penelitian ini, mengungkapkan bahwa, biaya yang sering terjadi dalam menjalankan roda bisnisnya adalah biaya perbaikan kran air, biaya perbaikan mesin pompa, dan biaya perbaikan kunci pintu kamar. jika melihat pada suatu kajian teoritis dari Hansen dan Mowen, biaya yang dikeluarkan dalam satuan aktivitas usaha jasa sewa kamar koskosan ini yang terdiri dari biaya listrik dan biaya perawatan masuk ke dalam sifat dari variable cost atau biaya variabel, yang berarti jumlah biaya yang dikeluarkan oleh pemilik mengikuti jumlah kamar yang telah disewakan. Sedangkan biaya langsung atau fixed cost nya adalah biaya gedung, dan sifat dari biaya campuran sendiri tidak ada dalam usahanya. Kategori sifat biaya yang terjadi dalam usaha Kos Putra Mulya ini digambarkan sebagai berikut:

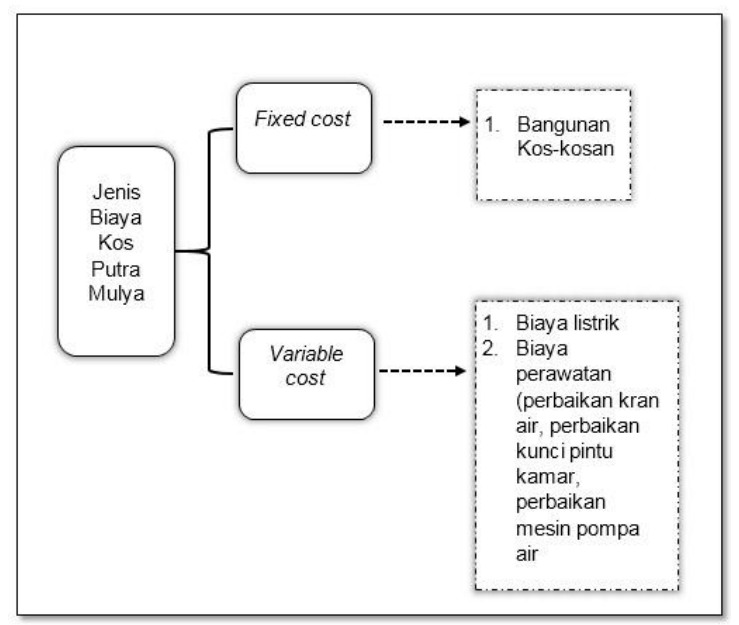

\section{Gambar 3.3 Jenis Biaya Usaha Kos Putra Mulya} Sumber: data olahan informan Bapak Toni

Paparan gambar di atas adalah jenis biaya yang terjadi pada aktivitas usaha Kos Putra Mulya. Bapak Toni yang paling berperan untuk tetap menjaga kualitas jasa yang dipasarkan, sehingga beliau cukup tau untuk masalah perbaikan dan perawatan bisnisnya. Lain dengan Ibu Susi, yang lebih berperan sebagai bagian hitung-menghitung jumlah pengeluaran dan pemasukan bulanan usahanya. Hitung-menghitung yang dimaksudkan adalah seperti menjumlah total biaya yang 
dikeluarkan untuk biaya perawatan, layaknya bendahara dalam sebuah organisasi. Namun, berdasarkan informasi wawancara dengan Ibu Susi, beliau tidak mencatat besarnya jumlah biayabiaya perawatan yang telah dibebankan. Namun, tidak menghalangi semangat Ibu Susi dalam menjalankan perannya sebagai pengusaha koskosan. Perhitungan-perhitungan yang dilakukan pun dilakukan penuh cinta, seperti yang senada dengan Ibu Susi dalam mencdritakan jumlah biaya-biaya yang telah dibebankan dalam kegiatan aktivitas usaha, berikut penjelasannya:

"kalo bayar lampunya itu ya \{habis banyak\} $n a k$, ya sekitar 350 tiap bulan itu, ya kadang-kadang 400 lah wis mentok itu. Soale kan disini \{pake pompa sanyojitu, ya lumayan nak habisnya. Ya kalo saya \{ndak dicatet\} nak berapa-berapanya itu, kalo semisal ada yang rusak ya langsung dibenerin, jadi saya gak nyatet berapa-berapanya", (Ibu Susi pemilik)

Berdasarkan hasil perbincangan dengan sang aktor, pencatatan untuk pengakuan biaya tidak dilakukan, hanya berdasarkan proses di luar kepala. Bentuk variable cost yang mendapat perhatian lebih dari Ibu Susi ialah biaya listrik, yang diakui perbulannya sebesar dari rentang Rp350.000 hingga Rp400.000. Tempat usaha koskosan yang dilakoni oleh Ibu Susi dan Bapak Toni menggunakan pompa air, tidak menggunakan PDAM, sehingga untuk tingkat pemakaian pompa air juga mendapat perhatian dari pemilik. Setelah pemakaian dari pompa air barulah tingkat pemakaian dari penyewa yang membawa alat daya listrik tinggi yang menjadi pusat perhatian pemilik, itulah sebabnya sang aktor menarik tarif lebih kepada penyewa yang membawa peralatan yang memakan daya listrik tinggi sebesar Rp15.000. Tingkat biaya-biaya yang telah dipaparkan pemilik tadi, maka untuk mendapatkan keuntungan atas usaha yang dijalaninya, minimal pemilik dapat memperkirakan keuntungan yang dapat menutupi biaya aktivitasnya. Sebelum memperkirakan laba yang akan diperoleh, dari keseluruhan biaya tersebut ditotal agar memudahkan aktor untuk melakukan perhitungannya.

Terdapat 2 jenis kamar dalam usaha Kos Putra Mulya, yang pertama bagi yang tidak membawa peralatan daya listrik tinggi dikenakan sebesar Rp270.000, dan tipe kamar yang kedua yang membawa peralatan daya listrik tinggi akan dikenakan biaya listrik tambahan sebesar Rp15.000, berikut perhitungan tarif sewa yang dilakukan oleh para aktor:

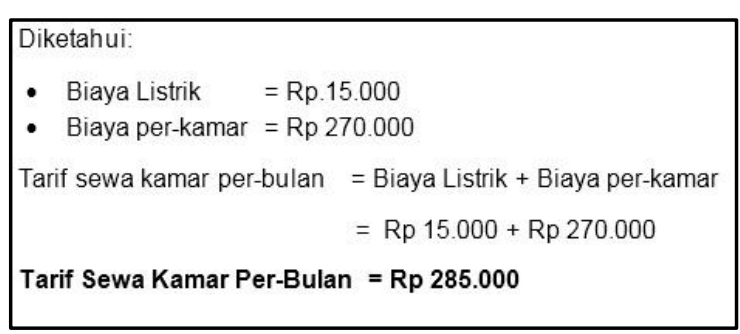

Gambar 3.4 Perhitungan Tarif Sewa Kamar Tipe 1 Sumber: data olahan informan Ibu Susi dan Bapak Toni

Sumber data yang berasal dari olahan observasi saya dengan aktor utama, menggambarkan ilustrasi perhitungan tarif sewa kamar Kos Putra Mulya. Untuk tipe kamar 1 ini bagi yang membawa peralatan tambahan yang akan memakan daya listrik tinggi, pemilik menetapkan untuk biaya per-kamarnya sebesar Rp270.000 yang didapat berdasarkan perkiraan, sehingga menurut pengakuannya biaya satuan kamar ini tidak ada aktivitas biaya lain yang mempengaruhi penentuan biaya tersebut, dan jumlahkan dengan biaya listrik tambahan sebesar Rp15.000, sehingga tarif harga sewa kamar tipe 1 ini sebesar Rp285.000 perbulan. Yang berikutnya adalah jenis tipe kamar 2 yang tidak membawa peralatan daya listrik tinggi, perhitungannya berdasarkan hasil olahan wawancara dengan informan sebagai berikut:

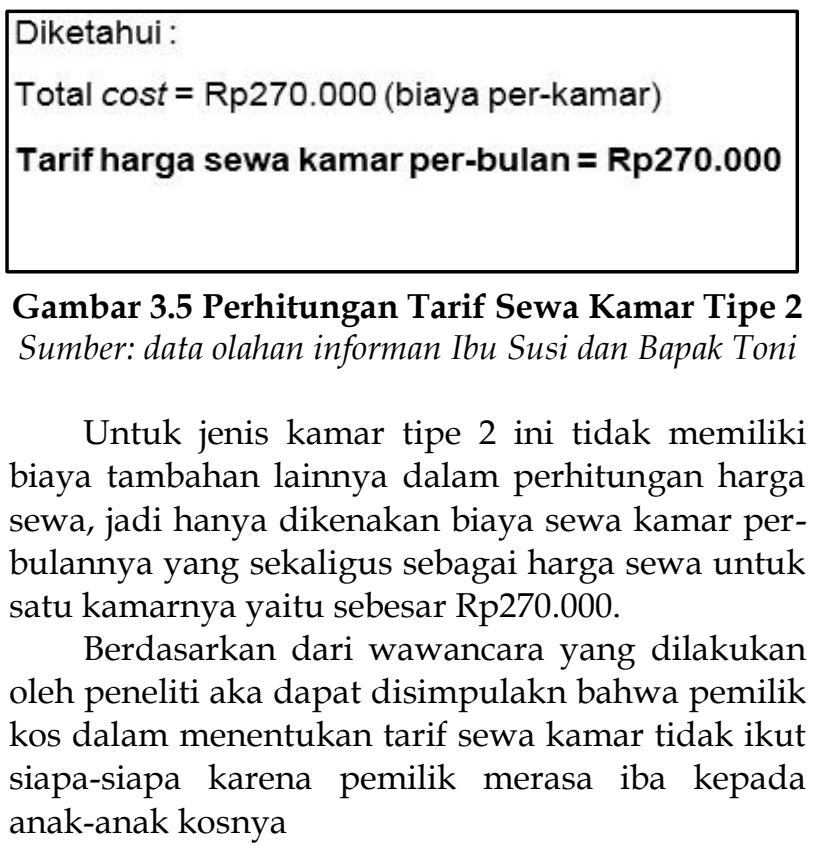




\subsection{PEMAKNAAN AKTOR}

\section{Budaya Gotong Royong Di balik Praktik Penentuan Harga Sewa}

Terdapat berbagai macam motivasi para pelaku bisnis untuk menaikkan suatu harga produk maupun jasa yang ditawarkan, dan salah satunya yang paling relevan adalah untuk meningkatkan laba atau keuntungan dari hasil penjualan produk atau jasa. Namun, alasan tersebut tidak sepenuhnya benar dan diadopsi oleh pelaku bisnis lainnya. Seperti oleh sang aktor yaitu Ibu Susi yang menceritakan bahwa jika menetapkan harga terlalu mahal akan memberatkan penyewanya, yang kemudian Ibu Susi menjelaskan perhitungan untuk menentukan biaya sewa kamar kos, berikut penjelasannya:

"ya 270 itu \{belum naik\} nak hehe, per kamar, ya 270 itu dari \{lampu, yang 15.000 bawa magicom\}, sudah itu. Tarif lampunya \{tiap bulan 15.000$\}$, \{biaya kosnya 270.000$\}$ tiap bulan, jadinya $\{285.000$ per kamar\}," (Ibu Susi - pemilik)

Dalam penjelasannya, Ibu Susi hanya mematok tarif sebesar Rp 270.000 untuk satu kamar dalam jangka waktu satu bulan masa sewa, ditambah dengan tarif listrik tiap bulan Rp 15.000. Kemudian Ibu Susi melanjutkan ceritanya mengenai biaya yang sering ditimbulkan dalam pengelolaan usahanya seperti yang diungkapkan oleh Ibu Susi, berikut penjelasannya.

"kalo bayar lampunya itu \{habis banyak\} nak 350 tiap bulan, ya 400 lah wis mentok itu. Lak \{memang banyak\}, lak mandi itu apa gak pake listrik? disini bukan PDAM, kalo PDAM lak banyak malah double, kalo \{biaya lain ya kadang-kadang ganti kran\}, \{perbaikan sanyo\}, mesti itu tiap \{bulannya ya 200 habis\}, terkadang ini aja 2 karena rusak kuncinya diganti", (Ibu Susi - pemilik)

Seperti yang dijelaskan oleh Ibu Susi bahwa, biaya yang sering ditimbulkan hanya biaya listrik, dimana untuk mengakui biaya listrik per-bulannya sebesar Rp 350.000 - Rp 400.000. keberadaan peneliti sebagai fenomenolog dengan mencoba menggali kesadaran individu pada akhirnya membuahkan hasil yang memberikan alasan dibalik penentuan biaya sewa yang telah ditetapkannya, berikut pernyataannya,

"ya gitulah nak, \{bantu-bantu sedikit\}, hehe. Yo tarif segitu bantu-bantu gitu lo nak, biar \{gak terlalu berat\}. Ya namanya anak sekolah nak, kan banyak mbayar-mbayar, fbuat makan aja terkadang kan susah\}, ini kan juga \{rumah saya sendiri\} jadi yaudah ya saya \{rawat sendiri\}", (Ibu Susi - pemilik)

Ibu Susi merasa bahwa penentuan tarif sewa kamarnya berdasarkan pada prinsipnya sendiri dimana harga tersebut sejumlah $\mathrm{Rp} 270.000$ ditambah dengan biaya listrik sebesar $R p 15.000$ tiap bulannya dan per-kamar, dan tidak menganggap biaya parawatan usaha. pendapat Ibu Susi sebagai bentuk kesadaran eksplisit (nоета) ini, disebabkan oleh niat Ibu Susi yang ingin membantu penyewanya agar tidak memberatkan, dan Ibu Susi belum menaikkan tarif sewanya, yang pada akhirnya membentuk kesadaran lebih dalam (noesis) bahwa tarif yang ditetapkan oleh Ibu Susi dianggap sebagai saling tolong-menolong. Pada titik ini, pemahaman atas "Aku" oleh Ibu Susi adalah "Aku menentukan tarif sewa kamar sendiri dan tidak mengikuti pengusaha kos lainyya dengan harga Rp 270.000 ditambah dengan biaya listrik sebesar $\mathrm{Rp} 15.000$ per-bulan, dan tidak menganggap biaya perawatan usaha karena Aku sadar bahwa jika tarif sewa kamarnya mengikuti pesaing lain tentu akan memberatkan konsumennya yang mayoritas mahasiswa".

Dengan berprinsip gotong royong dan saling tolong menolong pada penentuan harga sewa kamar turut dirasakan oleh konsumenya. Roni sebagai penyewa Kos Putra Mulya yang sudah selama 3 tahun menjadi konsumen merasakan biaya sewa yang dipatok oleh Bapak Toni dan Ibu Susi cukup murah, berikut penuturannya,

"Saya disini \{bayar nya perbulan\}, ini aku 275.000 per-bulan, saya segitu karna sendiri .kalo menurut saya disini \{sudah termasuk murah\}, soalnya gak ada yang satu kamar 135.000 \{sekarang itu ndak ada\}, \{paling kecil 150.000 - 175.000\}", (Roni - konsumen)

Roni merasa bahwa tarif sewa yang dibayarnya pada saat ini sudah termasuk murah, yaitu tarif per-kamar nya sebesar Rp 275.000 perbulan untuk satu kamarnya, sedangkan jika diisi berdua biaya sewa per-kamar nya menjadi Rp 135.000 per-bulan. Roni juga berpendapat tarif yang di patok oleh Bapak Toni dan Ibu Susi sudah termasuk murah dibanding dengan usaha kos lainya yang sudah dipatok sebesar Rp 150.000 - Rp 175.000 untuk diisi berdua, sehingga harga perkamarnya menjadi Rp 300.000 - Rp 350.000.

Masih dalam dimensi "tolong-menolong" dan "gotong-royong", peneliti kembali mencoba menggali kesadaran dari Bapak Toni. Sang aktor yaitu Bapak Toni menceritakan bahwa tarif yang ditentukan saat ini tidak mengikuti pengusaha kos lainnya, berikut penuturannya:

"enggak, \{saya gak ngikut patokan siapa-siapa\} tarif sewa kamarnya

saya bikin sendiri", (Bapak Toni - Pemilik)

Seperti itulah yang dikatakan oleh Bapak Toni, 
yang memiliki ciri khas sendiri dalam penentuan biaya sewa kamar. Keberadaan peneliti sebagai fenomenolog dengan mencoba menggali kesadaran individu pada akhirnya membuahkan hasil dan keluarlah pernyataan yang menjadi sebab pada penuturan awal Bapak Toni:

"sebetulnya \{mau dinaikkan bisa\} cuma mikir lagi gitu lo .....namanya anak sekolah kan biayanya banyak, iya kalo orang kaya orang tuanya, kalo biasa-biasa gini ni kan \{kaya tertekan\}, kaya terlalu berat gitu lo, ya wis cumapake harga sendiri itu", (Bapak Toni - Pemilik)

Begitulah yang dirasakan oleh Bapak Toni, yang sebenarnya memiliki keinginan untuk menaikkan tarif sewa kamarnya, namun disisi lain juga memikirkan kondisi penyewa yang justru takut memberatkan sehingga sang aktor tersebut memilih untuk menggunakan perhitungannya sendiri. Dalam wawancara yang berlangsung di ruang tamu pemilik usaha ini kembali menceritakan pengalaman usahanya, yang justru Bapak Toni mendapat masukan dari sepupunya sendiri yang juga sebagai pengusaha kos-kosan, beliau menyarankan agar tarif sewa kamarnya dinaikkan saja karena dianggap terlalu murah, berikut penjelasannya,

"loo sepupu saya di telang indah \{kan punya\}, saya tu \{bilang kisaran 270, loh ko murah banget\}, naikkan saja, saya bilang \{enggak, wis biar segitu aja\}. Sepupu saya itu yang ditelang indah terkejut kok bilang 270, loh kok pasang tarif segitu, murah itu, yaa saya bilang yowis \{biar namanya anak sekolah\}", (Bapak Toni - Pemilik)

Dalam penjelasannya, meskipun dianggap terlalu murah oleh sepupunya sendiri, Bapak Toni tetep pada pendiriannya yang menggunakan perhitungan sendiri dalam menentukan harga sewa kamar. Tujuan dari sang aktor untuk tetap tidak menaikkan harga sewa kamar yaitu ingin membantu dan saling tolong menolong dengan para penyewa, berikut pernyataannya,

“yowis tarif segitu \{itu itung bantu-bantu\} biar gak terlalu berat, emang

pikiran saya sama Ibu ya sama", (Bapak Toni pemilik)

Bapak Toni merasa bahwa tarif sewa kamar yang ditetapkan saat ini tidak mengikuti pesaing lain, melainkan menggunakan hitung-hitungan sendiri. Pendapat Bapak Toni sebagai bentuk kesdaran eksplisit (noетa) ini disebabkan oleh yang melihat keadaan pesaing lain mematok tarif yang terlalu mahal, dan merasa iba terhadap penyewa yang masih duduk di bangku kuliah, yang pada akhirnya membentuk kesadaran lebih dalam (noesis) bahwa tarif yang ditetapkan oleh Bapak Toni dianggap sebagai saling membantu agar tidak memberatkan konsumen. Pada titik ini, pemahaman atas "Aku menggunakan perhitungan tarif sewa kamar kos dan tidak mengikuti pesaing lain karena dengan perhitungan menggunakan tarif sendiri menganggap sebagai saling tolong menolong agar tidak memberatkan konsumen".

Namun berbeda dengan pengusaha lainnya seperti sepupu dari Bapak Toni, yang lebih memilih mematok harga minimal Rp 200.000 untuk satu orang sehingga jika dihitung dalam satuan kamar menjadi Rp 400.000 per-bulannya. Hal ini disebabkan oleh pengalamannya yang pernah merasa dibohongi oleh konsumen yang belum membayar sewa kamarnya. Peneliti dalam hal ini mencoba mengupas kesadaran dari Ibu Lisa terkait motivasinya yang lebih memilih menaikkan harga sewanya, berikut penjelasannya,

"Kalau di sini mas $\{470.000$ satu kamarnya\}, 235.000 satu orangnya, saya \{pertahun langsung dibayar\}. Soalnya pernah waktu dulu saya mulai buka usaha kos ini \{bayarnya bulanan\}, ada anak yang \{nakalan\} langsung kabur dia, saya tagih bilang nya belum ada ya saya telepon orang tuanya, sampek orang tuanya ke sini itu, bilangnya udah dikasihkan ke anaknya. Terus udah setelah itu \{saya usir\}, saya gak bisa nerima kamu lagi gitu saya bilangnya, pokoknyakalo di sini ada yang nakalan saya bilangin sekali dua kali gak mempan ssaya usir beneran mas\}", (Ibu Lisa - informan pendukung)

Kemudian Ibu Lisa menambahkan penjelasannya,

"Makannya di sini \{sepakat semua kos-kosan bayarnya pertahun\}, langsung pertahun supaya anak-anak itu \{ada tanggung jawabnya\}, udah \{gak ada mas di sini yang bayarnya perbulan\} itu, langsung pertahun semua. Soalnya saya udah kapok mas sama anak-anak yang susah kalo disuruh bayar", (Ibu Lisa - informan pendukung)

Dari penjelasannya tersebut, Ibu Lisa pernah menerapkan sistem pembayaran kos selama sebulan sekali, namun justru keadaan tersebut membuat penyewa tidak tertib membayar. Dengan begitu konsep pembayaran kos ala Ibu Lisa menetapkan satu tahun langsung dibayar tunai, agar penyewa lebih mempunyai tanggung jawab.

Tarif sewa kamar yang ditentukan oleh beberapa pengusaha kos-kosan juga berpatokan pada jauh dekatnya dengan lokasi kampus. Namun tidak dengan Bapak Andi yang merupakan tetangga dari Bapak Toni dan juga sebagai pengusaha sewa kamar kos-kosan, Bapak Andi mengatakan bahwa biaya sewa yang dipatok untuk 
penyewa adalah Rp 600.000 per-kamar, berikut penjelasannya,

"kalo disini $\{600.000$ per-kamar\}, jadi kalo \{diisi berdua 300.000. bayarnya langsung per-semester nak\}, gak boleh kalau per-bulan gitu, gak berani saya. Minimal per-semester, kalo semisal setahun langsung juga gak apa-apa, disini kalo listrik itu anak-anak iuran sendiri", (Bapak Andi - informan pendukung)

Pada keterangan dari Bapa Andi yang juga sebagai pengusaha kos-kosan, bahwa tarif sewa kamar dipatok pada harga Rp 600.000 per-kamar dengan sistem pembayaran langsung 6 bulan diawal masa sewa. Lokasi usaha Bapak Andi ini juga berlokasi di Telang Asri yang juga merupakan lokasi usaha Kos Putra Mulya yang dikelola oleh Bapak Toni.

Adanya nilai sosial di balik praktik penentuan harga sewa yang terjadi memberikan warna baru dalam ilmu akuntansi biaya khususnya. Budaya gotong-royong yang sangat kental dalam setiap nafas berbisnis yang dilakukan oleh para aktor mempunyai pengaruh terhadap keputusan atas suatu harga jasa, digambarkan seperti berikut:

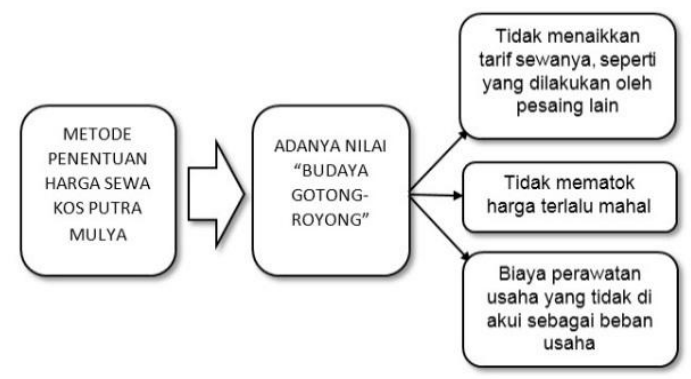

\section{Gambar 3.6 Pengaruh Budaya Gotong Royong Dalam Penentuan Harga Sewa \\ Sumber: data olahan 2017}

Terdapat 3 akun utama yang digunakan aktor dalam perhitungan penentuan harga sewanya yaitu biaya listrik, biaya per-kamar dan tarif sewa kamar per-bulan. Dengan begitu, jika memaknai nilai-nilai dibalik praktik penentuan harga sewa yang terjadidi terdapatnya unsur budaya gotong-royong yang melandasi aktor dalam menentukan tarif sewa kamar tersebut, berikut penjelasannya:
Tabel 3.2

Refleksi Nilai di Balik Penentuan Harga Sewa

\begin{tabular}{|c|c|c|}
\hline Nama Akun & Kesadaran aktor & $\begin{array}{l}\text { Memaknai nilai yang } \\
\text { terkandung }\end{array}$ \\
\hline Biaya Listrik & $\begin{array}{l}\text { Kesadaran aktor (lbu Susi } \\
\text { - pemilik), } \\
\text { "ya gitulah nak, bantu- } \\
\text { bantu sedikit hehe ya } \\
\text { namanya anak sekolah kan } \\
\text { banyak mbayar-mbayar, } \\
\text { buat makan aja terkadang } \\
\text { susah" }\end{array}$ & $\begin{array}{l}\text { tidak berpatokan kepada } \\
\text { kepuasan pemilik } \\
\text { semata, tidak egois, } \\
\text { dan adanya budaya } \\
\text { gotong-royong. }\end{array}$ \\
\hline Biaya per kamar & $\begin{array}{l}\text { Kesadaran aktor (Ibu Susi } \\
\text { - pemilik), } \\
\text { "yowis biar wong namanya } \\
\text { anak-anak sekolah. Yo tarif } \\
\text { segitu bantu-bantu gitu } 10, \\
\text { biar gak terlalu berat" }\end{array}$ & $\begin{array}{l}\text { Sebuah proses dalam } \\
\text { menyeimbangkan } \\
\text { hubungan aktivitas } \\
\text { keuangan antara } \\
\text { Manusia } \\
\text { sesama }\end{array}$ \\
\hline $\begin{array}{l}\text { Tarif sewa per-kamar } \\
\text { per-bulan }\end{array}$ & $\begin{array}{l}\text { Kesadaran aktor (Bapak } \\
\text { Toni - pemilik), } \\
\text { "kemarin saya mau naikkan } \\
\text { ke } 300 \text {, tapi saya juga mikir } \\
\text { sama ibu, kalo seandainya } \\
\text { terlalu mahal kosan itu } \\
\text { takut kemahalen, kan } \\
\text { anak-anak sekolahnya } \\
\text { banyak biaya juga" }\end{array}$ & $\begin{array}{l}\text { harga yang dibuat tidak } \\
\text { sekedar mengejar } \\
\text { unsur materi semata, } \\
\text { namun juga } \\
\text { mempertimbangkan } \\
\text { aspek manusianya }\end{array}$ \\
\hline
\end{tabular}

Sumber: data olahan 2017

\section{Membangun Rasa "Persaudaraan" Di Tengah Era Globalisasi}

Persaudaraan adalah sebuah ikatan yang dijalani antara individu satu dengan individu lainnya dan tidak melihat status, kasta, dan warna bahkan arti persahabatan dapat melebihi dari manisnya materialisme. Membangun rasa persaudaraan ke dalam suatu aktivitas keuangan tidaklah mudah, karena nuansa kapitalisme sudah menjadi mindset masyarakat saat ini dan sudah masuk ke dalam sendi-sendi kehidupan khususnya bagi masyarakat Indonesia sendiri.

Peneliti mengungkap kesadaran dari Bapak Toni sebagai aktor utama yang merupakan pemilik dari Kos Putra Mulya. Melanjutkan semangat serupa dalam mencari keunikan aktivitas keuangan Kos Putra Mulya, dimana Bapak Toni menganggap semua konsumennya seperti anak sendiri. Kondisi seperti ini sangat jarang terjadi, karena dampak dari jaman yang serba modern ini mengubah cara pandang dalam menjalankan roda bisnisnya, no money no honey adalah ungkapan yang serasi dengan paradigma masyarakat saat ini, yang hanya memburu keuntungan semata dan tidak memandang aspek-aspek nilai kemanusiaan dan rasa persaudaraan. Hal ini juga yang dirasakan oleh Bapak Toni yang menganggap semua konsumen adalah keluarga, berikut penjelasannya:

"ya kalo masuk sini ya memang tak anggep anak sendiri\}, \{bukan dianggap\} orang lain", (Bapak Toni - pemilik)

Bapak Toni menambahkan:

"kalo orang lain kan, \{gerbang ditutup\} ya gak 
bisa dibuka lagi, kalo saya engga, di sms "pak saya pulang jam sekian" ya saya tunggu, sms saya bales, gitu. Tapi pokoknya jam setengah 12 ya saya kunci, kalo seandainya pulang malem jam berapa gitu ya \{harus sms\}, gitu", (Bapak Toni - pemilik)

Begitulah penuturan oleh Bapak Toni, yang menganggap semua konsumennya adalah seperti anak sendiri. Rasa perhatiannya ditunjukkan seperti membuka gerbang kos jika ada konsumen yang pulang lebih dari jam 12 malam. Peneliti mencoba menggali lebih dalam lagi kesadaran dari aktor, sehingga muncul pernyataan aktor berikut ini:

"kaya kemaren yang kawinnya anak saya ini, kaya hamim itu. "kamu kalo \{seandainya nolongin\}, wis makan-makan sepuasnya" gitu, \{gausah bayar\}", (Bapak Toni - pemilik)

Bapak Toni kembali menambahkan pernyataannya:

"loo saya seandainya sepeda motornya ada diluar, saya suruh masukkan, biar \{gak ngundangngundang\} pikiran orang yang jelek, nah kalo tamu gak saya boleh masuk sepedanya", (Bapak Toni pemilik)

Begitulah pernyataan yang diungkapkan oleh Bapak Toni disaat wawancara berlangsung di ruang keluarga, Bapak Toni selaku pemilik juga memperhatikan aspek keamanan bagi penyewanya. Peneliti kembali mengupas kesadaran aktor yang meunculkan kesadaran seperti berikut:

"ya memang \{kaya anak sendiri\}, apalagi kalo disini ada acara apa ya apa, yowis anak-anak yang ada disamperin gitu. Disini keluarga sini \{gak punya perasaan kaya orang lain\}, enggak", (Bapak Toni pemilik)

Bapak Toni merasa bahwa semua konsumen yang menyewa kamar di Kos Putra Mulya sudah dianggap seperti anak sendiri. Pendapat Bapak Toni sebagai bentuk kesadaran eksplisit (noema) ini, disebabkan oleh kondisi lingkungan usahanya yang kental akan kekeluargaan dan rasa perhatian Bapak Toni kepada konsumennya seperti mengingatkan jika motornya lupa untuk dimasukkan, membuka pintu gerbang jika ada konsumen yang pulang lewat dari jam malam, yang pada akhirnya membentuk kesadaran lebih dalam (noesis) bahwa keluarga Bapak Toni sudah menganggap semua konsumen seperti layaknya keluarga sendiri dan tidak menganggap seperti orang lain. Pada titik ini, pemahaman atas "Aku" oleh Bapak Toni adalah "Aku memiliki rasa perhatian kepada konsumen karena Aku sadar bahwa sudah menganggap seperti anak sendiri dan keluarga, dan tidak menganggap seperti halnya orang lain".

Maraknya terjadi kejahatan pada usaha koskosan membuat Bapak Toni makin memperketat seluruh aktivitas usahanya. Hal tersebut dilakukan untuk melindungi konsumenya dari korban kejahatan seperti pencurian sepeda motor dan mencegah dari hal tersebut. Seperti pada penuturan Bapak Toni berikut ini:

"sebelum kamar belakang ditempati kamu \{saya pernah marahi\} anak-anak memang, laah wong masuk tengah malam motornya itu lo gak bilang saya, \{gak permisi\}, takmarahi, "laa kamu kan sudah mahasiswa, kan sudah ngerti, kan \{sudah dewasa\}, punya otak punya hati", gitu kata saya", (Bapak Toni - pemilik)

Dengan suasana wawancara yang santai diruang keluarga tersebut, Bapak Toni menceritakan keluhan kepada konsumen yang tidak izin terlebih dahulu ketika membawa sepeda motor, kemudian Bapak Toni kembali melanjutkan ceritanya:

"la bukan anak kos itu loo, tiba-tiba ada ditengah motornya. Tau-tau tengah malam itu \{ada motor baru\}, laa ini motor siapa, tak pikir kalo anak atas gak mungkin, ini anak bawah paling, abis itu langsung tak cari dibelakang tak gedor, tau-tau "iya" katanya, terus saya bilang "la kamu ini $\{g a k$ punya hati nurani\} ya, disini ini ada yang punya", ya takmarahi, maaf-maaf tok anaknya", (Bapak Toni - pemilik)

Dari suasana wawancara yang santai, peneliti dibuat tegang oleh beberapa pernyataan Bapak Toni terhadap kelakuan konsumen yang tidak izin ketika hendak membawa motor baru. Hal tersebut membuat Bapak Toni marah karena takut konsumen tersebut terlibat kejahatan pencurian, kemudian Bapak Toni kembali melanjutkan ceritanya seperti berikut:

"terus keluar anaknya sama temennya, ya gakpapa. Kalo \{anak kurang ajar\} itu gitu keluar ya silahkan. Cuma kalo anak kurang ajar gitu keluar \{gak nyesel\} saya", (Bapak Toni - pemilik)

Berdasarkan penjelasan Bapak Toni, yang pada akhirnya konsumen yang tidak mentaati peraturan keluar dengan sendirinya. Bapak Toni memang tidak pernah mengusir konsumen yang menurutnya "nakal", namun justru cukup memarahinya saja. Kedudukan peneliti sebagai fenomenolog berhasil menggali kesadaran lebih lanjut terhadap aktor, yaitu:

"sebetulnya anak-anak itu \{sudah dikasih\} tau, kalo temanmu mau nginep apa mau naro sepeda, saya tolong dikasih tau. Biar tau ini sepeda baik 
apa bukan", (Bapak Toni - pemilik)

Bapak Toni merasa bahwa sering menegur konsumen yang melanggar aturan seperti tidak izin jika membawa sepeda motor yang tidak dikenal. Pendapat Bapak Toni sebagai bentuk kesadaran eksplisit (noema) ini, disebabkan oleh kekhawatiran sang aktor terhadap maraknya kasus pencurian dan kejahatan di lingkup usaha sewa kamar kos, yang pada akhirnya membentuk kesadaran lebih dalam (noesis) bahwa jika hendak membawa sepeda motor yang tidak dikenal sebaiknya izin dulu supaya pemilik kos mengetahui keberadaan sepeda tersebut. Pada titik ini, pemahaman atas "Aku" oleh Bapak Toni adalah "Aku menegur kepada konsumen yang tidak izin ketika membawa sepeda motor yang tidak dikenal karena Aku sadar sudah menginfokan kepada semua konsumen bagi yang hendak membawa motor yang bukan milikknya, karena maraknya kejahatan dilingkup usaha sewa kamar kos"

Soal keamanan juga dirasakan oleh Roni. Konsumen yang sudah menyewa kamar di Kos Putra Mulya ini mejelaskan keamanan adalah hal yang terpenting, sehingga dalam memilih jasa sewa kamar kos tidak hanya melihat kenyamanan saja, namun kemanan juga diperhitungkan, berikut penjelasannya:

"dulu sih sempat \{ada rencana\} untuk pindah, tapi juga \{mikir-mikir\} lagi, kan \{ngekos gak nyaman nya saja\}, \{keamanan juga\} kan disini tau sendiri kaya apa", (Roni - konsumen)

Berdasarkan penjelasannya, Roni sempat mempunyai rencana untuk pindah kos, akan tetapi niat tersebut tidak dilakukan, karena merasa ditempat lain belum tentu memiliki keamanan yang terjaga seperti Kos Putra Mulya, kemudian Roni melanjutkan penjelasannya, seperti berikut ini:

"kalo saya kan awal saya disini \{walaupun kamar enggak dikunci\} ditinggal kemana-mana $\{g a k$ ada yang hilang\}, kalo dikos tempat lain kan \{belum tentu\} seperti itu", (Roni - konsumen)

Pengendalian internal yang dilakukan Bapak Toni terhadap konsumen dan lingkungan usahanya turut dirasakan juga oleh Roni, yang secara sadar mengatakan bahwa Kos Putra Mulya sudah termasuk aman meskipun pintu kamar tidak dikunci tidak terjadi kejadian kemalingan, sedangkan belum tentu di tempat lain seperti pada Kos Putra Mulya.

Menelisik lebih dalam kesadaran dari para aktor, terdapat bentuk nilai saling membangun persaudaraan antara pemilik usaha dengan penyewa. Esensi dari nilai yang terbentuk dalam relung kesadaran para aktor, membuktikan bahwa keuntungan bukanlah segalanya yang menjadi tujuan dalam berbisnis. Pada pembahasan kali ini, kesadaran yang peneliti temukan lebih kepada unsur rasa "persaudaraan" dibalik praktik penentuan harga sewa. Dengan menghadirkan rasa persaudaraan ke dalam suatu aktivitas keuangan, akan menghilangkan sifat akuntansi yang lebih bersifat maskulinitas, yaitu selalu mementingkan kepentingan individu, dan hanya berorientasi kepada laba. Adanya nilai persaudaraan digambarkan dalam berikut:

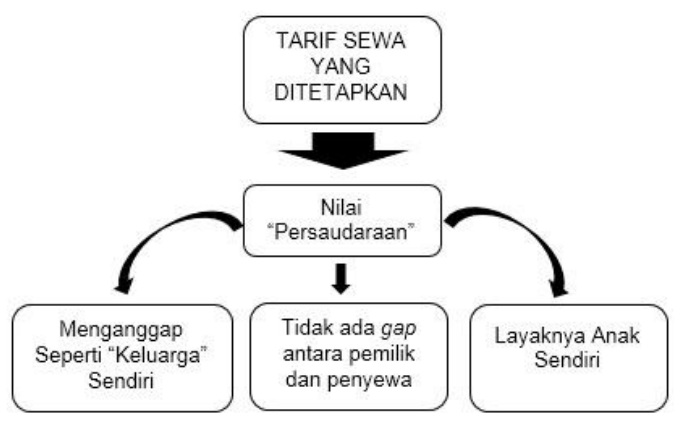

\section{Gambar 3.7 Nilai "Persaudaraan" Dalam Penentuan Harga Sewa Sumber: data olahan 2017}

\section{Pengakuan Laba Dalam Istilah "Keberkahan" : Suatu Refleksi}

Suatu keberkahan akan dicapai seseorang apabila telah melakukan sesuatu pekerjaan dengan jujur dan baik. Sifat keberkahan ialah abstrak dan tidak ada ukuran yang menentukan apakah seseorang tersebut telah mencapai keberkahan atau tidak. Hal ini disebabkan karena, adanya keterlibatan unsur ke-Tuhanan oleh setiap individu atau pelaku dalam satu kegiatan, baik kegiatan sehari-hari maupun kegiatan berbisnis. Dalam bab ini, peneliti kembali berusaha memaparkan hasil penggalian kesadaran dari aktor utama yaitu Ibu Susi dalam melakukan aktivitas keuangan didalam usahanya.

Jika dalam dimensi konvensional tentu tidak akan mengenal kata "rezeki", namun yang dikenal adalah "laba". Laba merupakan satu keuntungan entitas dari penjualan jasa maupun produknya kepada konsumen, jika penjualan tersebut tidak sesuai target maka yang diakui dalam entitas yaitu "rugi". Konsep akuntansi yang sangat menunjukkan maskulinitasnya juga berdampak pada paradigma masyarakat saat ini yang bertuhan kepada keuntungan atau profit oriented dan menghindari kerugian, yang berdampak pada persaingan ketat antar entitas dalam pemburuan 
laba.

Tidak ada salahnya memang kita berbicara soal bagaimana mendapatkan keuntungan dari hasil usaha yang saat ini dijalani, namun dirasa perlu untuk menyeimbangkan antara keperluan duniawi dan rohani yaitu dengan menghadirkan spiritualitas ke dalam suatu aktivitas keuangan. Dengan menghadirkan spritualitas dapat membuka pola pikir secara irasional bahwa manusia bukanlah siapa-siapa yang dapat menentukan segala hal di dunia. Peneliti mencoba menggali proses kesadaran terdalam aktor utama, yaitu Ibu Susi terkait dengan konsumen yang kabur dan mempunyai tunggakan sewa yang belum dibayar, berikut penjelasannya:

"ya kalo ada yang bayar kos per-semester fgak kira salah\}, lak kan ada yang \{bayar perbulan\}", (Ibu Susi - pemilik)

Lalu Ibu Susi melanjutkan ceritanya,

"ya anak-anak itu \{tiap bulan gak mesti\}. Bulan sekarang \{belum dibayar ya\}, bulan depan belum dibayar juga. masih bulan depan buk katanya, misalkan ini bulan berapa ? bulan 11 ya ? itu belum dibayar, dibayar nanti bu ya, pas bulan berikutnya itu \{juga belum mbayar\}, justru itu kan nunggak 2 bulan ya, itu juga gak bayar", (Ibu Susi - pemilik)

Dari hasil wawancara diatas, Ibu Susi menceritakan salah seorang konsumennya yang selalu menunda-nunda pembayaran sewa kamar, menurut cerita janjinya penyewa akan membayar bulan berikutnya akan tetapi masih belum dibayar, yang kemudian Ibu Susi melanjutkan ceritanya,

"kaya si budi itu, nanti \{bulan sekarang belum buk\} ya, nanti bulan depan. ya saya bilang iya. Cuma bilang iya tok terus dia bulan depan fjuga gak bayar\}, bilang nya nanti bulan 1, jadi 3 bulan nunggaknya, terus \{tau-tau kamarnya kosong\}, mek ada pakaiannya, terus dicari-cari ditelpon gak ada. Kaya si budi itu, kesini bilangnya apa ? minta maaf", (Ibu Susi - pemilik)

Pada hasil cerita Ibu Susi, menunjukkan kepasrahan sang aktor terhadap salah seorang konsumen yang secara tiba-tiba melarikan diri dan hanya menyisakan pakaian di dalam kamarnya. Dengan menggunakan sistem wawancara yang tidak terstruktur ini, peneliti berusaha menjadi pendengar yang baik dan lebih mengajak aktor seperti curhat, alhasil Ibu Susi kembali melanjutkan ceritanya,

"kesini sendiri terus \{bilang minta maaf\}, ini saya ambil pakaiannya katanya tuh, tapi saya negur gini, tapi kapan kamu 4 bulan yang mau mbayar ? dia jawabnya \{bulan depan\}, tapi satu minggu lagi saya kasih untuk bulan depan, ini hampir 2 bulan gak kesini\}", (Ibu Susi - pemilik)

Ibu Susi sebagai pemilik sudah menanyakan kapan penyewa tersebut bisa membayar tanggungannya, namun yang ditemukan justru penyewa tersebut tidak pernah kembali dan menghilang begitu saja, Ibu Susi yang sedikit kesal kembali melanjutkan curhatannya tersebut,

"hayo, kan \{sudah tua\} masa saya \{mau menjarakan dia\} kaya itu, masa saya \{mau geret-geret celanannya\} kan gak bisa, sudah saya tegur, saya tagih, yowis seperti itu nak", (Ibu Susi - pemilik)

Begitulah yang dirasakan oleh Ibu Susi. Melalui curhatan dari sang aktor, menjelaskan kekesalan dari tingkah konsumennya yang tidak mempunyai tanggung jawab. Ibu Susi yang secara kesal menjelaskan "sudah ditegur, sudah ditagih, masa saya mau memenjarakan, yowis seperti itu nak", dan Ibu Susi meneruskan curhatannya kepada pemilik,

"ya kalo \{saya sabar aja nak\}, cuek aja yowis. Makannya \{sekarang dianjurkan bayar 6 bulan\} sekali. Soalnya anak-anak nakal sendiri, ya kalo saya \{belum tak gitukan\}", (Ibu Susi - pemilik)

Demikian curhatan dari Ibu Susi yang menurutnya pembayaran sewa kamar kos pada saat ini dianjurkan 6 bulan langsung pembayaran, karena perilaku konsumen yang nakal itu sendiri, namun Ibu Susi tidak melakukan hal tersebut, peneliti berhasil menggali kesadaran terdalam dari aktor, berikut penjelasannya,

"kalo saya \{ya cuek aja\} nak, kalo rezeki saya ya pasti dikasih, kalo bukan rezeki saya ya terserah nak. Berarti kan anak itu nakalan, pokoknya saya gak nipu orang, pokoknya saya gituwis, saya gak nipu orang yang penting", (Ibu Susi - pemilik)

Ibu Susi merasa bahwa konsumen yang melakukan pembayaran sewa setiap 6 bulan sekali jarang terjadi masalah namun berbeda dengan konsumen yang membayar per-bulan. Pendapat Ibu Susi sebagai bentuk kesadaran eksplisit (noema) ini, disebabkan oleh pengalamannya yang sering memiliki konsumen bermasalah seperti mempunyai tunggakan hingga kabur dari tempat namun Ibu Susi pasrah, yang pada akhirnya membentuk kesadaran lebih dalam (noesis) bahwa jika itu bukan rezekinya maka biarlah, yang penting dalam menjalani usaha disertai dengan rasa jujur dan tidak merugikan orang lain dan konsumen. Pada titik ini, pemahaman atas "Aku" oleh Ibu Susi adalah "Aku merasa pasrah dengan konsumen yang memiliki masalah dalam pembayaran sewa kamar karena aku sadar jika menjalani usaha dengan jujur dan baik maka rezeki akan datang dengan sendirinya"

Dengan curhatan Ibu Susi diatas, tidak lantas 
membuat peneliti mempercayai begitu saja. Kemudian peneliti mencoba mewawancarai Roni sebagai informan pendukung yang pernah melihat kejadian tersebut secara langsung, berikut penjelasannya,

"kalo menurut saya itu \{ngawur\}, kalo kaya gitu \{pasti dicari\}, pasti ketemu. Kemarin ketemu dicari sama bu kos. Terus orangnya udah kesini, udah diambil kan barang-barangnya terus katanya kesini lagi katanya mau bayar semua tunggakannya, tapi \{nyatanya belum\} sampe sekarang", (Roni konsumen)

Seperti itulah cerita dari Roni yang membenarkan kasus konsumen yang melarikan diri dengan tanggungan yang masih belum dibayar. Wawancara yang berlangsung di dalam kamar Roni tersebut menceritakan kejadian sebenarnya lewat pengalaman dan kacamata si konsumen.

Informan pendukung peneliti lainnya yaitu Ibu Tutong juga pernah mengalami kejadian serupa dengan Ibu Susi terkait konsumennya yang melarikan diri, berikut penuturan cerita oleh Ibu Tutong,

"saya itu ya juga pernah nak, ada anak itu ya yang kabur \{belum bayar 600.000\} ke saya, ya langsung kabur menghilang gitu aja, sudah saya telpon anaknya katanya \{Cuma iya-iya tok nak\}, yasudah sampe sekarang yo \{gak dibayar\}, makannya kenapa usaha kos-kosan saya yang itu saya \{jadikan sistem kontrak\}, langsung dibayar per-tahun, \{supaya yang sewa itu ada tanggung jawabnya\}, sekarang saya sudah gak mau nerima yang bulanan, makannya saya kontrakkan sekarang", (Ibu Tutong - informan pendukung)

Pengalaman Ibu Tutong yang pernah mengalami serupa seperti Ibu Susi membuat suatu landasan dalam menentukan biaya sewanya, semula pembayaran boleh dilakukan perbulan namun berubah menjadi sistem kontrak dengan pembayaran setahun.

Pada pembahasan kali ini merupakan puncak kesadaran paling dalam dari aktor utama yaitu Ibu Susi. Melanjutkan dari proses pada pembahasan sebelumnya dimana hal yang menjadi landasan dalam penentuan harga sewa pada Kos Putra Mulya adalah budaya gotong royong dan rasa persaudaraan, yang kemudian muncul suatu istilah "keberkahan". Suatu pencapaian yang tidak akan diakui apabila setiap usaha dilakukan dengan praktik secara konvensional.

Ibu Susi memperlihatkan suatu bentuk refleksi apabila suatu aktivitas keuangan memperhatikan aspek kejujuran, tidak mengambil hak orang lain, dan memperhatikan unsur kemanusiaan maka esensi dari "keberkahan" itu sendiri akan dapat dirasakan. Dengan membawa Tuhan dalam setiap kegiatan berbisnis, setiap orang yang melakukan kegiatan berbisnis akan dilimpahkan rasa syukurnya atas apa yang dilakukan. Maka, hal ini akan membangun hubungan antara manusia dengan sang pencipta dengan memaknai bahwa rezeki bukanlah suatu tentang hitung-hitungan yang dapat diketahui jumlahnya, akan tetapi dengan membawa budaya gotong-royong dan rasa persaudaraan ke dalam suatu metode penentuan harga sewa, rezeki itu akan datang dengan sendirinya, namun jika kerugian yang dialami maka cukup dengan memaknai "bukan rezekinya". Dengan begitu skema penentuan laba dengan menggunakan metode penentuan harga sewa Kos Putra Mulya digambarkan sebagai berikut:

\section{KESIMPULAN}

Pendekatan yang peneliti lakukan adalah fenomenologi yang pada akhirnya mencapai puncak dari proses penggalian kesadaran. Penentuan biaya sewa kamar merupakan fokus utama dalam penelitian ini, yang diangkat dari praktik bisnis usaha jasa sewa kamar yang memiliki keunikan dengan dimensi budaya bangsa Indonesia dalam setiap segmen penentuan biaya sewanya.

Inflasi akan berdampak pada kenaikan harga suatu jasa maupun produk, namun tidak bagi Kos Putra Mulya yang memilih untuk tidak menaikkan harga sewa kamar Berdasarkan hasil wawancara peneliti dengan informan, yang secara sadar bahwa takut memberatkan penyewanya jika tarif sewa kamarnya dinaikkan, hal ini karena mayoritas konsumen dari Kos Putra Mulya yang berstatus mahasiswa. Hasil analisis fenomenologi juga menunjukkan alasan dibalik keputusan informan untuk tidak menaikkan harga, yaitu menganggap tarif yang ditetapkan saat ini "bantu-bantu" atau saling membantu antara pemilik dan penyewa. Salah satu kesadaran dari informan tersebut memiliki nilai budaya gotong royong yang saat ini keberadaannya makin tergerus oleh arus pusaran global .

Konsep akuntansi modern lebih mengedepankan unsur materialisme, yaitu menekankan pada pertimbangan angka dan laba semata. Sudah seharusnya konsep tersebut diganti oleh semangat gotong-royong yang menempatkan manusia dalam hal ini penyewa sebagai landasan dalam membuat keputusan biaya sewa yang akan ditetapkan. Selain terdapatnya nilai budaya 
"gotong royong", juga ada unsur "kemanusiaan" di dalam penentuan biaya sewa kamar. Karena harga yang ditentukan oleh informan tidak sekedar mengejar unsur materi semata, namun juga mempertimbangkan aspek manusianya. Seperti kesadaran informan yang sebetulnya ingin menaikkan harga sewa kamar, namun "takut kemahalan" jika hal itu dilakukan.

Peneliti juga menemukan rasa persaudaraan yang timbul antara pemilik dengan para konsumennya. Berdasarkan hasil analisa peneliti melalui analisis fenomenologi, informan lebih menunjukkan rasa perhatian kepada konsumennya yang sudah dianggap seperti anak sendiri. Dengan menghadirkan rasa persaudaraan ke dalam suatu aktivitas keuangan akan menghilangkan sifat maskulinitas yang selalu berorientasi kepada laba.

Pada hal tersebut akan menciptakan proses menuju pengangkatan derajat manusia, dimana konsumen harus menjadi tujuan utama. Akuntansi harus dibuat dengan berorientasikan kesejahteraan bersama, sehingga yang dilakukan oleh informan dibalik biaya sewa yang telah ditentukan tidak hanya dibuat demi tujuan kepentingan bisnis semata, namun juga memperhatikan sisi penyewa sebagai salah satu unsur pembentuk dan penggerak usaha yang dijalani informan tersebut. Dalam hal ini nilai dibalik praktik penentuan biaya sewa yang dilakukan oleh aktor peneliti yaitu Bapak Toni dan Ibu Susi tidak hanya bertujuan untuk meningkatkan laba keuntungan usaha, namun juga untuk tujuan bersama.

Dan yang terakhir bermuara kesadaran terdalam informan yang mengakui suatu keuntungan dengan istilah "keberkahan". Informan menunjukkan kesadaran dibalik penentuan harga sewa yang dilakukan dengan memperhatikan aspek kejujuran, kemanusiaan. Hal tersebut dapat dilihat dari hasil analisis fenomenologi yang tidak memarahi dan menghakimi konsumennya ketika mempunyai tanggungan pembayaran sewa kamar, karena informan meyakini jika memang sudah rezekinya pasti akan datang namun jika bukan rezekinya maka cukup di ikhlaskan.

Temuan selanjutnya yaitu kesadaran informan yang tidak melibatkan pihak lain jika salah seorang konsumen yang tidak tertib dalam pembayaran sewa kos. Menurut hasil analisis fenomenologi, informan yang secara sadar mengatakan jika melakukan hal tersebut akan membuat malu bagi si penyewa, dalam kondisi seperti ini informan masih saja memperhatikan sudut pandang para penyewanya.
Sehingga, pada titik ini informan memiliki sikap kerendahan hati yang secara sadar merasa bahwa dirinya bukanlah siapa-siapa dalam kehidupannya, sehingga refleksi kesadaran informan terdapatnya unsur nilai ketuhanan. Dengan menghadirkan Tuhan dalam penentuan biaya sewa akan jauh meninggalkan paham kapitalisme yang tidak memperhatikan aspek kemanusiaan dan rasa saling tolong menolong.

\section{Keterbatasan Penelitian}

Tak ada manusia yang terlahir sempurna, kesempurnaan hanya milik Tuhan. Begitupun juga dengan penelitian ini yang jauh dari kata sempurna, yang masih memiliki banyak keterbatasan dari berbagai aspek. Keterbatasan yang pertama adalah peneliti kurang mengupas pengalaman pengelolaan keuangan usaha koskosan pada salah satu informan pendukung dikarenakan sikap kurang terbukanya informan pendukung, sehingga pengungkapan pengalaman tersebut kurang dalam, namun sudah cukup untuk mengkonfirmasi dari pernyataan informan utama peneliti terkait tarif sewa kamar kos.

Yang kedua adalah peneliti tidak bisa mengungkap kesadaran dan pengalaman konsumen yang melarikan diri dari Kos Putra Mulya, dikarenakan informan yang sulit dihubungi dan tidak tau domisili saat ini. Sehingga, peneliti mengungkap kasus konsumen yang tidak bertanggung jawab melalui kacamata penyewa lainnya yang mengetahui kebenaran kejadian tersebut.

\section{Saran Penelitian}

Hasil dari penelusuran lorong penelitian ini diharapkan dapat memberikan sumbangsih saran terutama untuk peneliti selanjutnya yang ingin melanjutkan semangat serupa. Bagi peneliti selanjutnya, bisa menempatkan pada topik pengelolaan keuangan usaha kos-kosan, tentunya harus memiliki keunikan dalam pengelolaan keuangannya tersebut. Selain usaha kos-kosan peneliti selanjutnya dapat membidik jasa sewa kamar hotel yang dapat diungkap keunikan penentuan harga sewa maupun pengelolaan keuangannya melalui pendekatan etnografi, jika ada unsur budaya yang mempengaruhi dalam pengelolaan keuangan maupun penentuan biaya sewa nya. Begitu juga dengan usaha sewa menyewa lainnya seperti sewa kendaraan, sewa menyewa lahan tempat berdagang, sehingga penelitian mengenai penentuan harga sewa berlandaskan nilai-nilai kearifan lokal dapat masuk ke dalam entitas bisnis lainnya selain usaha jasa sewa kamar kos. 


\section{DAFTAR PUSTAKA}

Alimuddin, Iwan Triyuwono, Gugus Irianto, GrahitaChandrarin. (2011). KonsepHargaJualKejujuran: MeraihKeuntunganMenggapaiKemaslahatan. JurnalAkuntansiMultiparadigma"JAMAL", 1-185 Vol.2 No.1.

Borgias, F. 2014. ArtiPenting "Refleksi" dalamDuniaPendidikan. Retrieved from PusatInovasipembelajaranUniversitasKatolikParahyangan:http://pip.unpar.ac.id/publikasi/buletin / sancaya-volume-03-nomor-01-edisi-januarifebruari-2015/arti-penting-refleksi-dalamdunia-pendidikan/Diakses pada tanggal 12 September 2016 pukul 20.45

Don R. Hansen, Maryanne M. Mowen. 2009. Akuntansi Manajerial. Jakarta: Salemba Empat.

Hajaroh, M. 2010. Paradigma, PendekatandanMetodePenelitianFenomenologi.BidangKeahlianpenelitiandanevaluasipendidikan , FIP UNY, 9-10

Hardiansyah, A 2013. TeoriPengetahuan Edmund Husserl. JurnalSubstantia, Vol. 15 No.2 Hal. 236.

Hasbiansyah, O. 2005. PendekatanFenomenologi :PengantarPraktikPenelitiandalamIlmuSosiald anKomunikasi. MEDIATor, 163-180

Kamayanti, A. 2016. METODOLOGI PENELITIAN KUALITATIF AKUNTANSI :PengantarReligiositasKeilmuan. Jakarta: YayasanRumahPeneleh.

Kuswarno, E. 2013. Fenomenologi. Bandung: WidyaPadjajaran.

Mabrur, I. 2016. Prospek Usaha Kos-Kosan. Retrieved from Amanah Solution Care to all: http://www.amanahsolution.com/index.php /11-wawancara/33-prospek-usaha-kos-kosan Diakses pada tanggal 14 September 2016 pukul 19.30

MertzhaDwiputriRiediansyaf, Basuki. 2013. Designing Time-Driven Activity-Based Costing (TDABC) in the Room Division at Hotel X Malang: an Exploratory Case Study Approach. SimposiumNasionalAkuntansi XVI.

Moleong.2013. MetodePenelitianKualitatif, EdisiRevisi. Bandung: PT. RemajaRosdakarya

Molisa, P. 2010. Don't look at my finger; look at the moon. Critical Perspectives on Accounting, ELSEVIER, 533-535.

Mulyadi. 2014. AkuntansiBiaya, Edisi 5. Yogyakarta: UPP STIM YKPN

Oktavianingtyas, F. M. 2015. MenyelamiKesadaranWajibPajakPengusahaIndekosAtasKe(Tidak)PatuhanPembayaranPajakUsahan ya. KaryaTulisIlmiah.
PropertiIndonesiaku.com 2015. KelebihandanKekuranganSewaKost. Retrieved from Propertilndonesiaku: www.propertiindonesiaku.com/article/kelebi han-dan-kekurangan-sewa-kost_Diakses pada tanggal 25 November 2016 pukul 09.20

Rahmat, P. S. 2009. PenelitianKualitatif. EQUILIBRIUM, 1-8 Vol. 5, No. 9

Sarwono, J. 2006. MetodePenelitianKuantitatifEKualitatif. Yogyakarta: GrahaIlmu.

ShaviraZalshabila, AjiDediMulawarman. 2012. Javanese Price Setting: RefleksiFenomenologisHargaPokokProduksiPedagangBakso Di Kota Malang. JurnalAkuntansiMultiparadigma "JAMAL", Vol.3 No.2.

Smith, J. A. 2009. Psikologikualitatif: Panduanpraktismetoderiset. Terjemahandari Qualitative Psychology A Practical Guide to Research Method. Yogyakarta: PustakaBelajar.

Somantri, G. R. 2005. MemahamiMetodeKualitatif. MAKARA, SOSIAL HUMANIORA, 57-65 Vol. 9 No. 2.

Sugiyono.2010. MetodePenelitianBisnis. Bandung: Alfabeta.

Sugiyono.2015. MetodologiPenelitianKuantitatif, Kualitatifdan $R \in \mathcal{E}$. Cetakan 22. Bandung: Alfabeta 